\title{
Adaptations of two specialist herbivores to movement on the hairy leaf surface of their host, Solanum guaraniticum Hassl (Solanaceae)
}

\author{
Lenice Medeiros $^{1} \&$ Danessa S. Boligon ${ }^{2}$
}

\author{
${ }^{1}$ Departamento de Biologia e Química, UNIJUI, Rua do Comércio, 3000, Bairro Universitário, 98700-000 Ijuí-RS, Brasil. \\ lemedeiros13@yahoo.com.br \\ ${ }^{2}$ Programa de Pós-Graduação em Biologia Animal, UFRGS, Av. Bento Gonçalves 9500, Bloco IV, Prédio 43435, 91501-970 Porto Alegre-RS, \\ Brasil. daniboligon@ig.com.br
}

\begin{abstract}
Adaptations of two specialist herbivores to movement on the hairy leaf surface of their host, Solanum guaraniticum Hassl (Solanaceae). Plant trichomes can difficult the attachment and movement of small insects. Here, we examine the hypothesis that the success on the use of densely haired hosts by two cassidine species is determined by differential morphology and behavior. Larvae of Gratiana graminea (Klug, 1829) and Gratiana conformis (Boheman, 1854) move on the leaf surface of their host, Solanum guaraniticum Hassl by anchoring their tarsungulus on the trichome rays or by inserting the tarsungulus tip directly into epidermis. This kind of movement is only possible due to a similar tarsungulus shape among the species. Tarsungulus growth pattern is also similar between species, being relatively small on the posterior aperture, matching the diameter of the host plant trichome rays. The tarsungulus shape associated with differences on ontogenetic growth and attachment pattern allow these two Cassidinae larvae to efficiently move on the pubescent leaf surface of their host.
\end{abstract}

KEYWORDS. Cassidinae; Gratiana; morphological adaptation; tarsungulus; trichomes.

RESUMO. Adaptações de dois herbívoros especialistas ao movimento, em folhas com tricomas do sua hospedeira, Solanum guaraniticum Hassl (Solanaceae). Os tricomas foliares podem dificultar a fixação e o movimento de pequenos insetos. Neste trabalho, testamos a hipótese de que o sucesso na exploração de plantas com folhas densamente cobertas por tricomas é determinado pela morfologia e comportamento diferenciados em duas espécies de cassidíneos. As larvas de Gratiana graminea (Klug, 1829) e Gratiana conformis (Boheman, 1854) se movem sobre a superfície foliar de sua hospedeira, Solanum guaraniticum Hassl através do ancoramento de seus tarsúngulos no raio dos tricomas estrelados da planta ou da inserção da ponta desta estrutura diretamente na epiderme. Tais tipos de movimento só são possíveis devido à forma dos tarsúngulos, a qual é similar nas duas espécies. O padrão de crescimento dos tarsúngulos das espécies estudadas é também similar e apresenta-se relativamente menor na abertura posterior, correspondente ao diâmetro dos raios dos tricomas estrelados. A forma dos tarsúngulos, associada às diferenças no seu padrão de crescimento permite às larvas destas duas espécies de Cassidinae se moverem com eficiência sobre a superfície pubescente de sua planta hospedeira.

PALAVRAS-CHAVE. Adaptação morfológica; Cassidinae; Gratiana; tarsúngulos; tricomas.

Trichomes represent a plant morphological trait that can impose resistance to herbivore insects (Levin 1973; Johnson 1975; Fernandes 1994; Wagner et al. 2004). Evidences from cultivated and wild plants support the idea that trichomes act as mechanical defense that impede movement on leaf surface, restrict access to food and/or diminish food digestibility and assimilation (Schillinger \& Gallun 1968; Gilbert 1971; Rathcke \& Pool 1974; Pillemer \& Tingey 1976; Belcher \& Thurston 1982; Brewer et al. 1983; Smith \& Grodowitz 1983; Ramalho et al. 1984; Hoffman \& McEvoy 1986; Fordyce \& Agrawal 2001; Valverde et al. 2001; Kennedy 2003). In addition to mechanical defense, some plant glandular trichomes secret toxic chemicals and/or sticky exudates that may entrap and kill small insects (Thurston 1970; Smith et al. 1975; Tingey \& Gibson 1978; Shade et al. 1979; Tingey \& Laubengauer 1981; Duffey 1986; Neal et al. 1989; Yencho \& Tingey 1994; van Dam \& Hare 1998; Gurr \& McGrath 2002).

On the other hand, certain insects developed behavioral traits to surpass the barriers imposed by plant trichomes and guarantee their success in using pubescent hosts. Larvae of some Lepidoptera and Coleoptera use their mandibles to cut and remove leaf trichomes in order to clear a patch of hairs before establish a feeding site (Hsiao 1986; Hulley 1988; Medeiros \& Vasconcellos-Neto 1994; Zalucki 2001; Medeiros $\&$ Moreira 2005). The gregarious larvae of Mechanitis isthmia (Lepidoptera: Ithomiinae) avoid the leaf trichomes of their host by spinning a network of silk over the spines tops, above which they crawl safely (Rathcke \& Pool 1974). Also, there are evidences for the existence of insect morphological modifications to overcome the barriers imposed by trichomes and their exudates (Kennedy 1986 a, b; Moran 1986; Southwood 1986). For example, Dicyphus errans (Hemiptera, Miridae) presents very long tibia and modified tarsi structure that avoid the leg contact to the the tip of the host glandular trichomes, which secret a gummy exudate when touched (Southwood 1986). Recent studies showed for larvae of six cassidine species a convergence on tarsungulus shape associated with differences in ontogenetic growth, which contribute to an efficient movement on both glabrous and pubescent surfaces (Medeiros et al. 2004). 
Seven species have been ascribed for the neotropical genus Gratiana Spaeth, 1913. Five of them are known to feed on Solanum L. (Solanaceae) and tend to be host specific (Siebert 1975; Buzzi 1988, 1994; Borowiec 1996, 1999; Olckers et al. 2002). The effects of Solanum trichomes as a defense mechanism against herbivores are widely studied, mainly regarding the role of their exudates (Gibson 1978; Tingey \& Gibson 1978; Obrycki \& Tauber 1984; Gregory et al. 1986; Neal et al. 1989; Yencho \& Tingey 1994; Hill et al. 1997). However, the corresponding mechanical effects are relatively poorly explored. Medeiros \& Moreira (2002) showed that the stellate trichomes of Solanum sisymbriifolium Lam. (Solanaceae) act as a mechanical barrier to Gratiana spadicea (Klug, 1829) (Cassidinae) larval movement, mainly for the first three instars. To move across the pubescent host leaf surface, G. spadicea larvae present a tarsungulus morphology and growth pattern adapted to anchor their legs on the trichomes, and thus moving above them (Medeiros \& Moreira 2002).

At the Northwest of Rio Grande do Sul State, Gratiana conformis and G. graminea are commonly found sharing the same individual plants of Solanum guaraniticum (Medeiros et al. 1996; Nogueira-de-Sá et al. 2004), whose leaf surface is densely pubescent. The aim of this study is to characterize the larval leg morphologies and morphometries of these two Cassidinae, and to describe the way by which they attach and move on the hairy leaf surface of Solanum guaraniticum.

\section{MATERIAL AND METHODS}

Insects and plants. Adults and immatures of G. conformis and $G$. graminea were field collected from nearby wild $S$. guaraniticum plants, and kept in a laboratory chamber $(25 \pm$ $1{ }^{\circ} \mathrm{C}$; L14:D10; $\left.c a .70 \% \mathrm{RH}\right)$, existing at the Zoology Laboratory of University of Ijuí (UNIJUI), Ijuí, RS, Brazil (28²3’18" S). The plants used for insect feeding, to study behavioral trials and trichome characterization, were field collected also from the vicinity of UNIJUI Campus. Leaves of the same age were used, and there was no indication they presented different size or trichome density.

Leaf characterization. Leaf squares of $S$. guaraniticum $\left(c a .1 \mathrm{~cm}^{2}\right)$ were cut with a pair of scissors and immediately fixed in FAA 50\% solution. They were immersed overnight in acetone, and then critical point dried. The dried leaf squares were mounted on aluminum stubs and coated with goldpalladium, using a Balzers Union ${ }^{\circledR}$ sputter coater. They were observed and photographed in a Jeol 5800® scanning electron microscope. For morphometric characterization, the stellate trichomes were removed at random with fine pointed forceps from the abaxial surface ( $c a .0 .5 \mathrm{~mm}^{2}$ per surface) of $S$. guaraniticum leaves ( $\mathrm{n}=20$ leaves; three trichomes per leaf). The corresponding groups of detached trichomes were slide mounted in water and the images obtained from a microscope connected to a digitalizing plate and a video camera. The length, diameter at the tip, middle and base of the trichome rays and peduncle were taken by using the Image tool ${ }^{\circledR}$ software.
Stellate trichome density was recorded for the abaxial leaf surface $\left(c a .1 \mathrm{~mm}^{2}\right)$ of fully expanded leaves $(\mathrm{n}=30)$.

Leg morphometrics. Leg length of both Gratiana species $(\mathrm{n}=10$ per instar per species) was measured as the distance from the proximal margin of the coxa to tibial tip (Fig. 1a). To measure the tarsungulus, individuals $(\mathrm{n}=10$ per instar per species) were clarified in a hot, $10 \% \mathrm{KOH}$ solution, dehydrated in an ethanol series (50, 70, 90 and 100\% ethanol), immersed in xylol, and slide mounted in Canada balsam. The width of the tarsungulus basis and its aperture at anterior, median and posterior positions (Fig. 1b) were also measured. The tarsungulus consists of the distal portion of larval legs, and results from the fusion of the tarsus and pre-tarsus (Crowson 1981; Lawrence 1991). To compare the growth pattern of these leg structures with other Gratiana body parts, we also measured the larvae head capsule width ( $\mathrm{n}=10$ per instar per species), which corresponded to the distance between the posterior stemmata. Data were submitted to a regression analysis $(\alpha=0.05)$. The best-fit equations were determined by comparing the sum-of-squares using the F-test (Graph pad Prism 3.0).
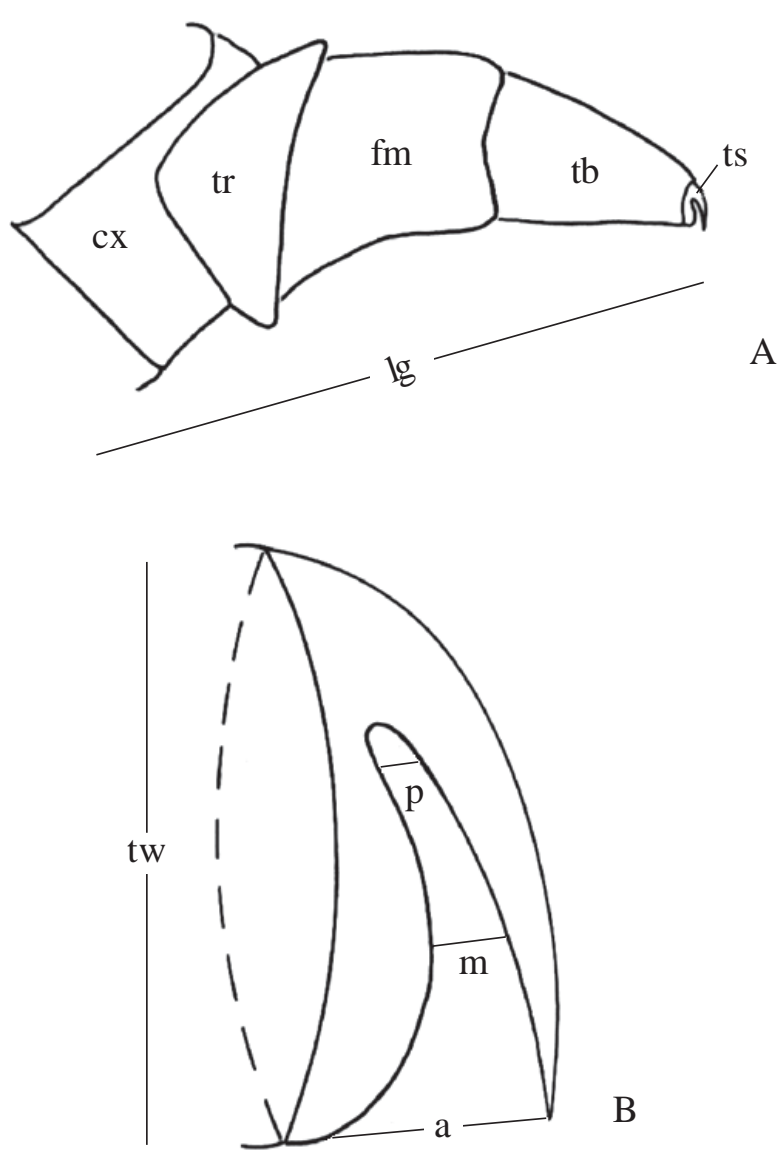

Fig. 1. A - Schematic representation of a cassidine (Gratiana spadicea) larval leg $(\mathrm{cx}=$ coxa, $\mathrm{fm}=$ femur, $\mathrm{tb}=$ tibia, $\operatorname{tr}=$ trochanter, $\mathrm{ts}=$ tarsungulus), and corresponding length measure (LL arrow); B schematic representation of its tarsungulus, and corresponding measures $(\mathrm{a}=$ anterior aperture, $\mathrm{m}=$ median aperture, $\mathrm{p}=$ posterior aperture, and $\mathrm{tw}=$ tarsungulus width). (from Medeiros \& Moreira, 2002). 


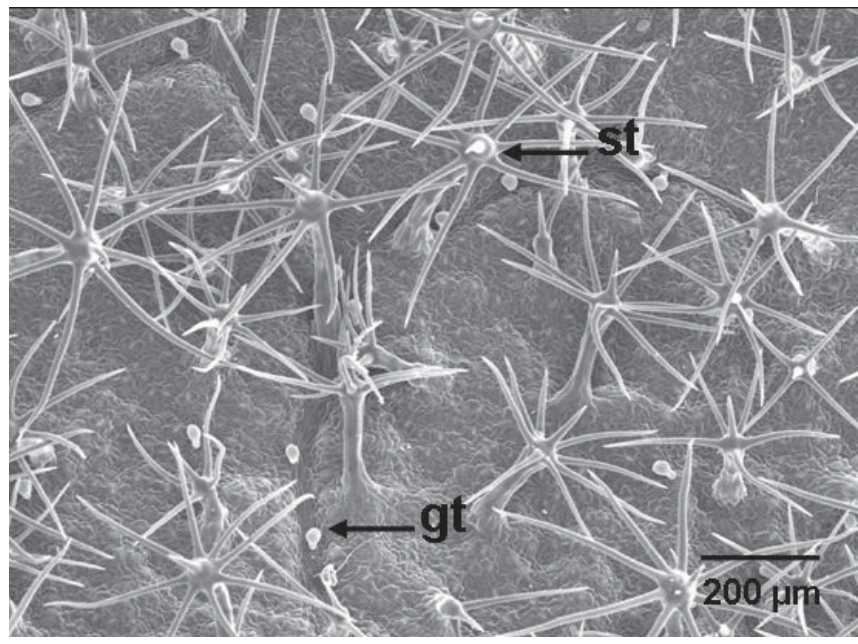

Fig. 2. Solanum guaraniticum. Overview of the abaxial leaf surface showing the stellate (st) and the simple glandular trichomes (gt).

Larval movement. To describe which leaf structures are used as attachment for larval movement on $S$. guaraniticum abaxial leaf surface, focal observations ( $\mathrm{n}=20$ individuals per instar per species) were made under a stereomicroscope during three minutes. As a given individual moved during observations, the corresponding leg position in relation to either the ray of different types of trichomes or epidermis was identified, and recorded. The data were transformed to frequencies and compared using Chi-square tests $(\alpha=0.05)$.

\section{RESULTS}

Leaf characterization. Leaves of S. guaraniticum are densely covered by stellate and simple glandular trichomes. The stellate type presents a puricellular peduncle and, in general, seven to eight lateral rays arising from a common point (Fig. 2). These correspond to the multiangulated type described by Mentz et al. (2000). The number of stellate
Table I. Ratios between the mean larval head capsule width, and that of leg length (LL), tarsungulus width (TW), tarsungulus aperture on the anterior (AA), median (MA), and posterior (PA) portions of Gratiana conformis and $G$. graminea.

\begin{tabular}{lcccccc}
\hline Species & $\begin{array}{c}\text { Larval } \\
\text { instar }\end{array}$ & LL & TW & AA & MA & PA \\
\hline Gratiana & I & 1.16 & 5.49 & 7.80 & 18.31 & 36.92 \\
conformis & II & 1.11 & 5.61 & 9.36 & 24.90 & 44.33 \\
& III & 1.06 & 5.75 & 10.48 & 35.03 & 60.92 \\
& IV & 1.02 & 5.94 & 10.23 & 38.34 & 71.22 \\
& V & 0.97 & 6.11 & 9.62 & 39.41 & 85.60 \\
Gratiana & I & 1.09 & 7.06 & 9.07 & 22.41 & 41.17 \\
& II & 1.08 & 6.55 & 9.72 & 25.35 & 48.28 \\
& III & 1.03 & 6.87 & 11.00 & 31.20 & 57.27 \\
& IV & 0.98 & 7.33 & 12.30 & 31.61 & 64.48 \\
& V & 1.03 & 7.04 & 9.24 & 30.59 & 80.03 \\
\hline
\end{tabular}

trichomes in the abaxial leaf surface was $12.78 \pm 0.45 / \mathrm{mm}^{2}(\bar{X} \pm$ $\mathrm{SE} ; \mathrm{n}=30)$. The corresponding trichome rays were longer $(0.47$ $\pm 0.011 \mathrm{~mm} ; \mathrm{n}=144)$ and thinner $(25.6 \pm 4.5 \mu \mathrm{m})$ than the peduncles $(0.29 \pm 0.012 \mathrm{~mm}$ length, and $52.3 \pm 7.3 \mu \mathrm{m}$ thickness; $\mathrm{n}=42$ ).

Leg morphometrics. The tarsungulus of both Gratiana larvae are heavily sclerotized, corresponding to a terminal hooked structure with a sharp tip in continuation to the distal edge of the tibia (Fig. 3). Although G. conformis larvae and adult body is slightly larger than that of $G$. graminea, their larvae share the same pattern of ontogenetic growth of the body parts considered here. Tarsungulus aperture increases in size from its posterior to anterior end. For both Gratiana, exponential growth was recorded for the head capsule, leg length, and tarsungulus width (Fig. 4). Also, the anterior portion of the aperture grows exponentially throughout the larval instars (Figs. 5a and d). In contrast, the posterior and median portions of the tarsungulus aperture increase relatively
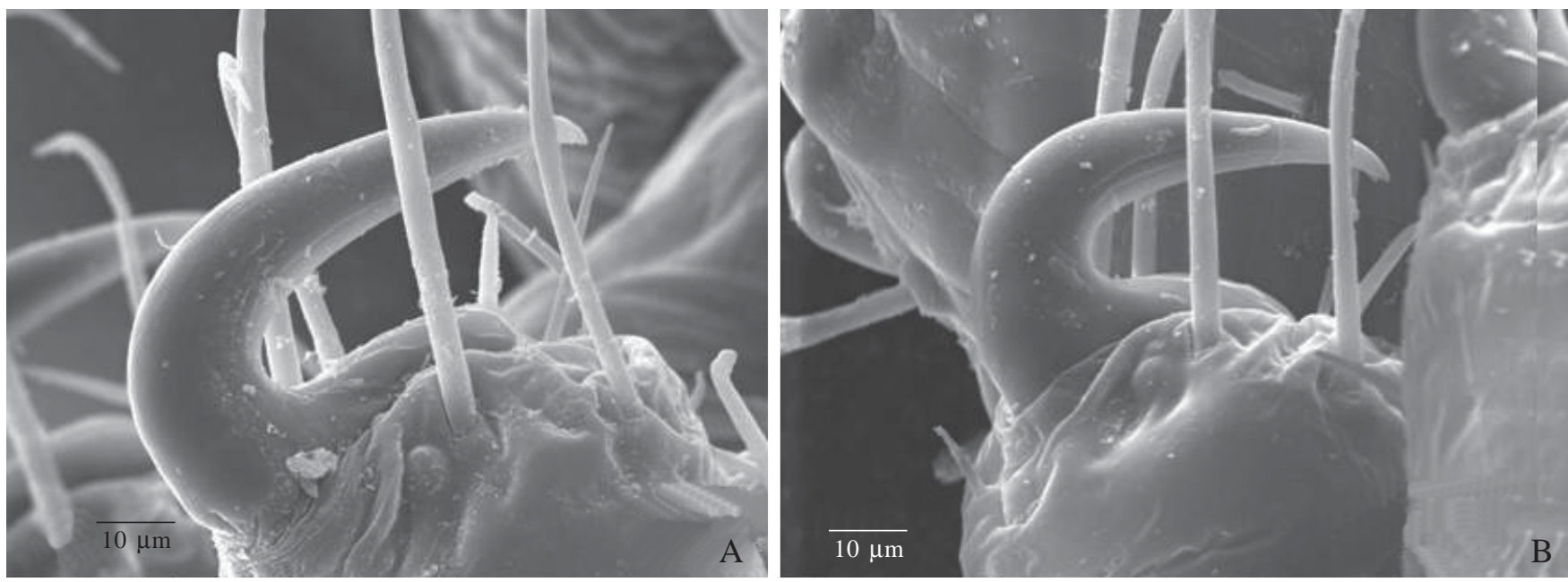

Fig. 3. Tarsungulus of Gratiana conformis (A), and G. graminea (B) larvae. 

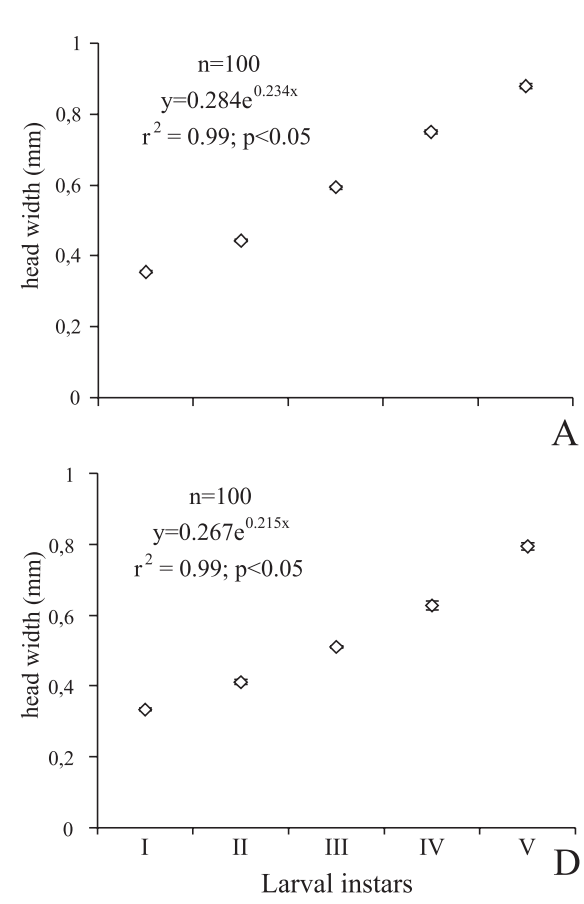
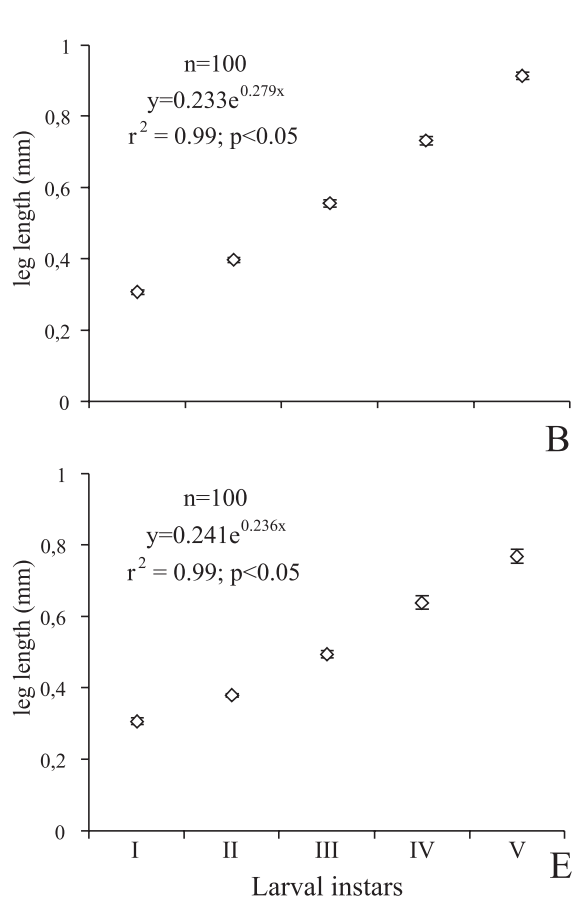

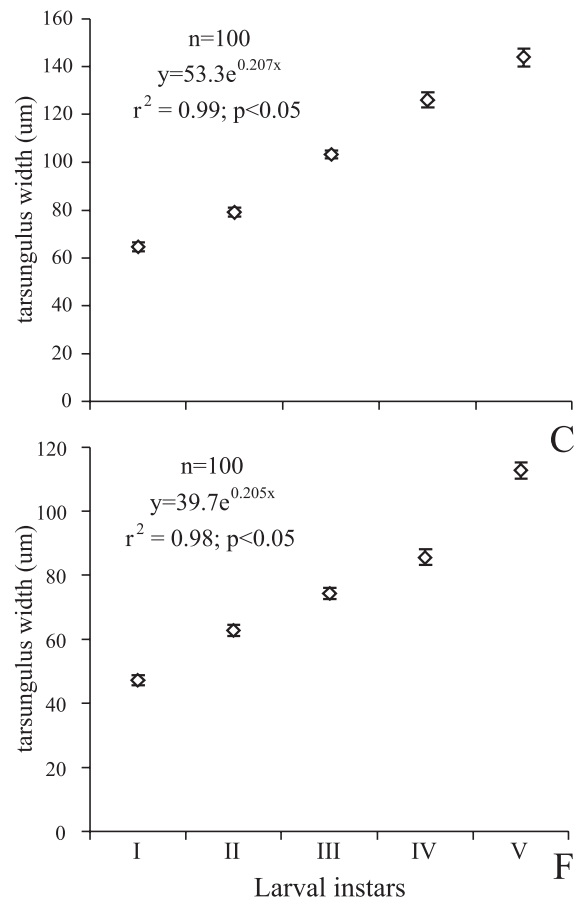

Fig. 4. Growth pattern of head capsule, leg length, and tarsungulus width (mean \pm standard error) in the larval stage. A, B, and C - Gratiana conformis; D, E, and F - G. graminea.

slight with larval instars for both species (Figs. 5b, c, e and f). As a consequence, the growth ratio between the head capsule width and for both middle and posterior aperture size progressively increases among instars, while the corresponding ratio remains similar for the anterior aperture, leg length and tarsungulus width (Table I).

Larval movement. The larvae of both Gratiana species move mainly by anchoring the tarsungulus hook on the trichome rays, but occasionally they also move by inserting the tarsungulus tip directly into the epidermis. This second type of movement is more frequent for latter instar larvae (Fig. 6).

\section{DISCUSSION}

Plant trichomes can confer resistance to movement and feeding to herbivorous insects, and also to their natural enemies (Levin 1973; Shah 1982; Belcher \& Thurston 1982; Brewer et al. 1983; Gamarra et al. 1998; Fernandes 1994). Also, their negative effects are in many cases inversely related to the size of the organisms, and so the younger are generally more vulnerable to their harmfulness (Schillinger \& Gallun 1968; Tingey \& Launbengayer 1981; Hoffman \& McEvoy 1986a; Wellso \& Hoxie 1988; Van Dam \& Hare 1998; Fordyce \& Agrawal 2001; Zalucki et al. 2002). Considering that many Cassidinae are very closely associated to their hosts (Buzzi 1988, 1994; Jolivet \& Hawkeswood 1995), and that their larvae are relatively small, it is reasonable to expect that they must present adaptations to surpass barriers imposed by high density of trichomes. Here, we found that both Gratiana species present a similar tarsungulus shape that allow larvae to move on the very pubescent leaf surface of their host, $S$. guaraniticum. Such a pattern has already been described for other Cassidinae larvae (Medeiros \& Moreira 2002; Medeiros et al. 2004). The tarsungulus seems to represent a well adapted attachment structure to exploit leaves varying from glabrous to densely pubescent.

The tarsungulus hook allows the larval anchorage on the trichomes of hairy leaf surfaces. In fact, larvae that exploit densely pubescent leaves as those of $S$. guaraniticum, must move above and/or between the trichomes by anchoring the tarsungulus hook on the trichome rays, such as observed herein. Medeiros et al. (2004) showed that the higher frequencies of this type of movement are registered for larvae that feed on more densely pubescent plants, in particular those with higher density of stellate trichomes. Larval anchorage in this way is only possible due to the tarsungulus morphology, and probably to variation on their morphometry, as the tarsungulus aperture at the median and posterior portions grows isometrically along the larval stage, while the other body parts grow exponentially. Also, these aperture dimensions present a correspondence with the trichome peduncle and ray diameter, where larvae anchor the tarsungulus. The same pattern was observed for other cassidine species that exploit pubescent hosts, while on the contrary those associated to glabrous plants present exponential growth on those body parts (Medeiros \& Moreira 2002; Medeiros et al. 2004). 

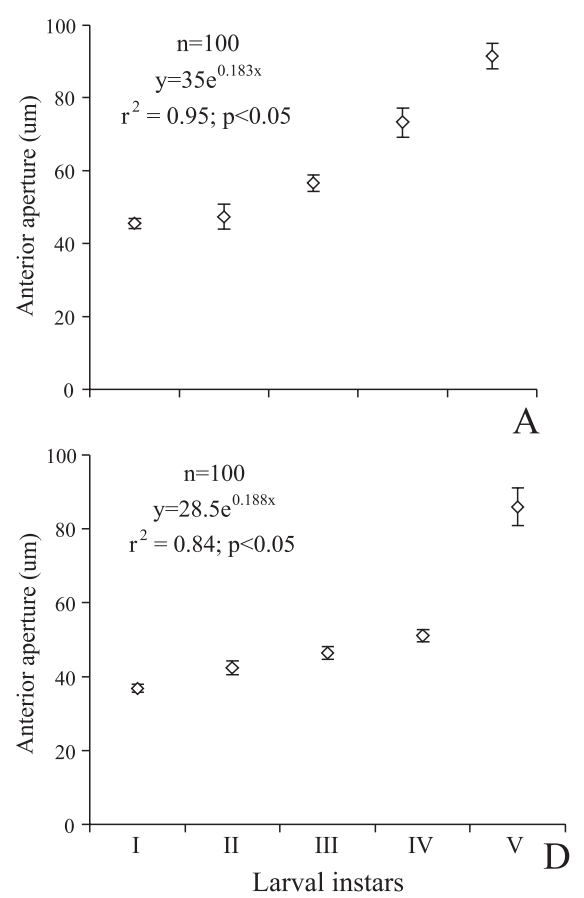
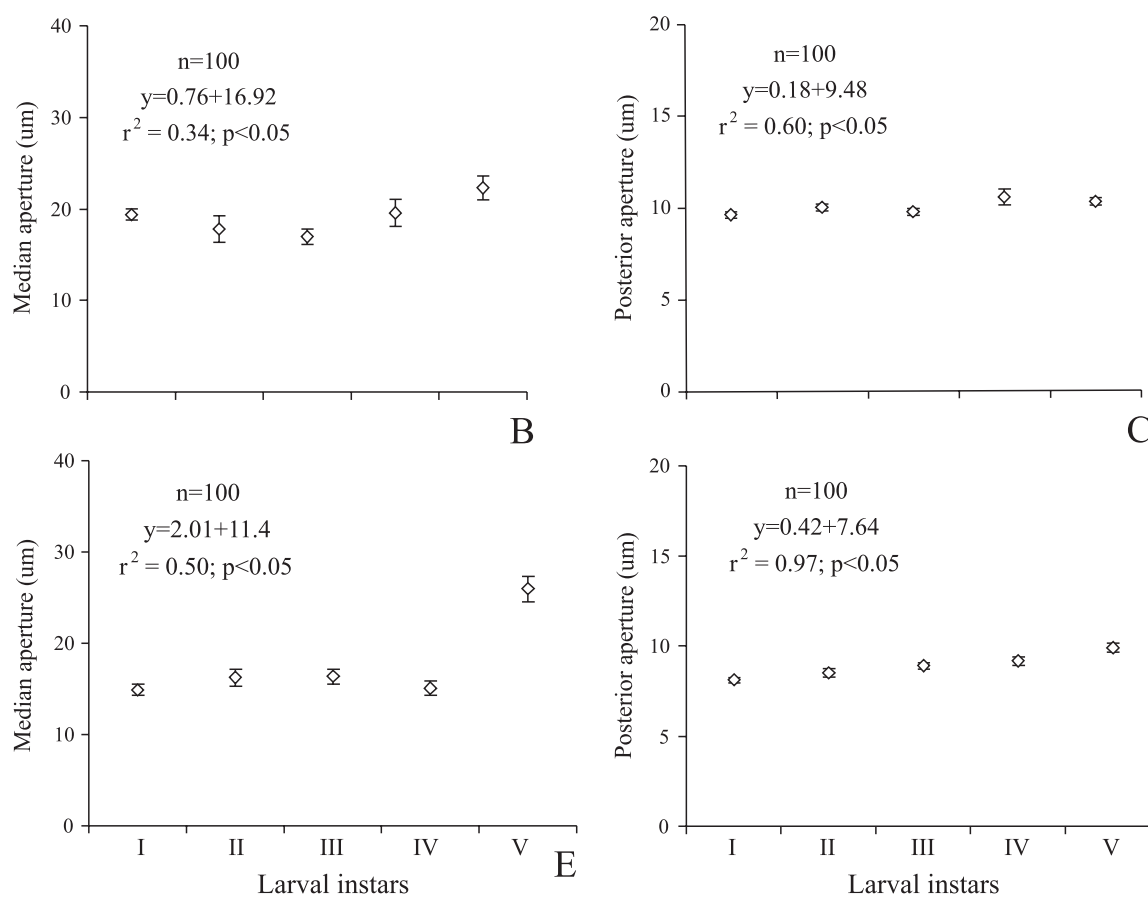

$\mathrm{C}$

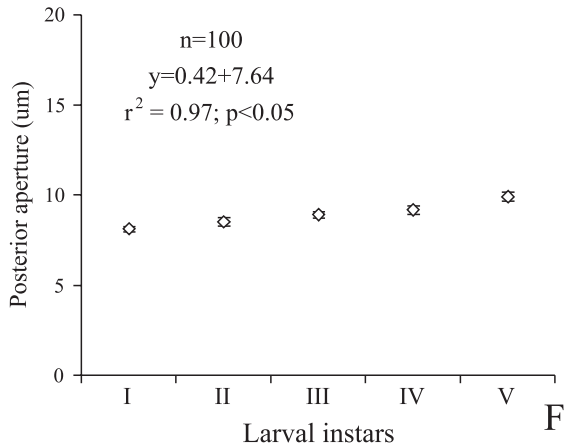

Fig. 5. Growth pattern of tarsungulus aperture at the anterior, median and posterior portions (mean \pm standard error) throughout larval stage. A, B, and C - Gratiana conformis; D, E, and F - G. graminea.

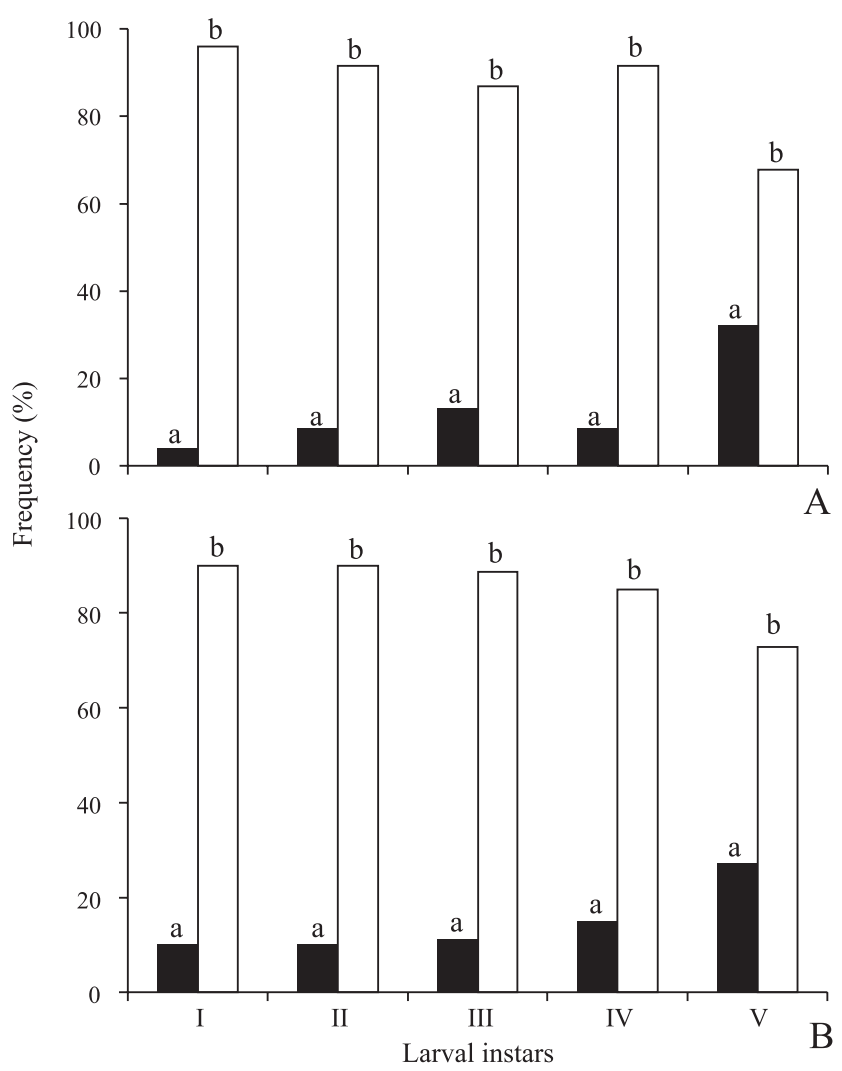

Fig. 6. Tarsungulus position of Gratiana conformis (A) and G. graminea (B) larvae ( $\mathrm{n}=20$ per instar per species) while moving on Solanum guaraniticum leaf surface. Dark bars = epidermis; open bars = stellate trichomes. Bars followed by different letters, within each instar, differ significantly (Chi-square tests; á $=0.05$ ).
The sharp end of the tarsungulus allows the larvae to attach and move by inserting the tip directly into the leaf epidermis. This type of movement was described for oak aphids, and called "tiptoeing" or walking on the claws by Kennedy (1986 a, b). It occurs preferentially on glabrous or low trichome density surfaces that permit the larvae to move among their rays, and seems to be a common strategy of many insects, since leaf surfaces are generally smooth and relatively easy to perforate with a sharp claw. The Gratiana larvae here studied also walk on the claws, but in a relatively low frequency, except during the fifth instar. This movement is difficult for small larvae because their legs are shorter than the trichome peduncle and central ray, so they can not reach the epidermis under high density of stellate trichomes, as occurs in $S$. guaraniticum leaves. Hence, their movement must occur above the trichomes, which is possible given the morphological modifications of the tarsungulus.

Thus, from a morphological perspective, it seems clear that the tarsungulus shape and ontogenetic growth pattern favors the larvae of G. conformis and G. graminea to successfully move on the hairy surface of their host.

Acknowledgements. The authors wish to thank Moema Q. Vieira, and Dr. Gilson R.P. Moreira, for scanning electron microscopy facilities in Centro de Microscopia Eletrônica (CME)/UFRGS; to Dr. Lilian A. Mentz for plant identification; to Sidnei Bortolon and Ana Paula Noronha for their help in the laboratory. We are also grateful to Dr. Daniela Rodrigues for suggestions that improved the manuscript. Financial support came from FAPERGS (ARD to L. Medeiros) and from a CNPq Scholarship (PIBIC) to D.S. Boligon. 


\section{REFERENCES}

Belcher, D. W. \& R. Thurston. 1982. Inhibition of movement of larvae of the convergent lady beetle by leaf trichomes of tobacco. Environmental Entomology 11: 91-94.

Borowiec, L. 1999. A world catalogue of the Cassidinae (Coleoptera: Chrysomelidae). Biologica Silesiae, Wroc 3 aw, XI+476 p.

Borowiec, L. 1996. Faunistic records of Neotropical Cassidinae (Coleoptera: Chrysomelidae). Polish Journal of Entomology 65: 119-251.

Brewer, M.; D. K.Gorla \& M. E.Garay. 1983. Caracterización de los estadios ninfales del género Triatoma Laporte, 1983. II Análisis biométrico descriptivo de Triatoma infestans Klug, 1834; Triatoma platensis Neiva, 1913; Triatoma delpontei Romaña y Avalos, 1947 y Triatoma sordida Stal, 1859 (Hemiptera, Reduviidae). Revista de la Sociedad de Entomología Argentina 42: 81-88.

Buzzi, Z. 1988. Biology of Neotropical Cassidinae, p. 559-580. In: P. Jolivet; E. Petitpierre \& T. H. Hsiao (eds.). Biology of Chrysomelidae. Kluwer Academic Publishers, Dordrecht, xxiv+615 p.

Buzzi, Z. J. 1994. Host-plants of Neotropical Cassidinae, p. 205-212. In: P. H. Jolivet; M. L. Cox \& E. Petitpierre (eds.). Novel aspects of the biology of Chrysomelidae. Kluwer Academic Press, Dordrecht, xxiii+582 p.

Crowson, R. A. 1981. The Biology of Coleoptera. Academic Press. London. 802 p.

Duffey, S. S. 1986. Plant glandular trichomes: their partial role in defense against insects, p. 151-172. In: B. Juniper \& T. R. E. Southwood (eds.). Insects and the plant surface. Edward Arnold Publishers, London, viii+360 p.

Fernandes, G. W. 1994. Plant mechanical defenses against insect herbivory. Revista Brasileira de Entomologia 32: 421-433.

Fordyce, J. A. \& A. A. Agrawal. 2001. The role of plant trichomes and caterpillar group size on growth and defence of the pipevine swallowtail Battus philenor. Journal of Animal Ecology 70: $997-$ 1005 .

Gamarra, D. C.; V. H. P. Bueno; J. C. Moraes \& A. M. Auad. 1998. Influência de tricomas glandulares de Solanum berthaultii na predação de Scymnus (Pullus) argentinicus (Weise) (Coleoptera: Coccinellidae) em Myzus persicae (Sulzer) (Homoptera: aphididae). Annais da Sociedade Entomológica do Brasil 27: 59-65.

Gibson, R. W. 1978. Resistance in hair glandular potatoes to flea beetles. American Potato Journal 55: 595-599.

Gilbert, L. 1971. Butterfly-plant coevolution: has Passiflora adenopoda won the selectional race with Heliconiine butterflies? Science 172: 585-586.

Gregory, P.; D. Ave; P. J. Bouthyette \& W. M. Tingey. 1986. Insectdefensive chemistry of potato glandular trichomes, p. 173-184. In: B. Juniper \& R. Southwood (eds.). Insects and the Plant Surface. Edward Arnold Publishers, London, viii+360 p.

Gurr, G. M. \& D. McGrath. 2002. Foliar pubescence and resistance o potato moth, Phthorimaea operculella. Lycopersicon hirsutum. Entomologia Experimentalis et Applicata 103: 35-41.

Hill, M. P.; P. E. Hulley; J. Allsopp \& G. Van Harmelen. 1997. Glandular trichomes on the exotic Solanum sisymbrifolium Lamarck (Solanaceae): effective deterrents against na indigenous South African herbivore. African Entomology 5: 41-50.

Hoffman, G. D. \& P. B. McEvoy. 1986. Mechanical limitations on feeding by meadow spittlebugs Philaenus spumarius (Homoptera: Cercopidae) on wild and cultivated hosts. Ecological Entomology 11: 415-426.

Hsiao, T. H. 1986. Specificity of certain chrysomelid beetles for Solanaceae, p. 345-363. In: W. G. D’Arcy (ed.). Solanaceae: Biology and Systematics. Columbia University Press, New York, $\mathrm{XII}+603 \mathrm{p}$.

Hulley, P. E. 1988. Caterpillar attacks plant mechanical defense by mowing trichomes before feeding. Ecological Entomology 13: $239-241$

Johnson, H. B. 1975. Plant pubescence: an ecological perspective. The
Botanical Review 41: 233-258.

Jolivet, P. \& T. J. Hawkeswood. 1995. Host-plants of Chrysomelidae of the world. Backhuys Publishers, Leiden, xiii+281 p.

Kennedy, C. 1986a. Tiptoeing through the trichomes or could attachment to the host plant matter to host selection? Antenna 10: $75-79$

Kennedy, C. 1986b. Attachment may be a basis for specialization in oak aphids. Ecological Entomology 11: 291-300.

Kennedy, G. G. 2003. Tomato, pests, parasitoids, and predators: tritrophic interactions involving the genus Lycopersicon. Annual Review of Entomology 48: 51-72.

Lawrence, J. F. 1991. Order Coleoptera, p. 144-184. In: F. W. Stehr (ed.). Immature insects, vol. 2. Kendal Hunt Publishing Company, Dubuque, xvi +975 p.

Levin, D. A. 1973. The role of trichomes in plant defense. The Quarterly Review of Biology 48: 3-15

Medeiros, L. \& G. R. P. Moreira. 2005. Larval feeding behavior of Gratiana spadicea (Klug) (Coleoptera, Chrysomelidae, Cassidinae) on its host plant, Solanum sisymbrifolium Lamarck (Solanaceae): interaction with trichomes. The Coleopterist's Bulletin 59: 339-350

Medeiros, L. \& G. R. P. Moreira. 2002. Moving on a hairy surface: modifications of Gratiana spadicea larval legs to attach on its host plant, Solanum sisymbrifolium. Entomologia Experimentalis et Applicata 102: 295-305.

Medeiros, L. \& J. Vasconcellos-Neto. 1994. Host plants and seasonal abundance patterns abundance patterns of some Brazilian Chrysomelidae, p. 185-189. In: P. H. Jolivet, M. L. Cox \& E. Petitpierre (eds.). Novel aspects of the biology of Chrysomelidae. The Kluwer Academic Publishers, Dordrecht, $\mathrm{xxiii}+582 \mathrm{p}$.

Medeiros, L.; D. N. Ferro \& A. Mafra-Neto. 1996. Association of Chrysomelid beetles with solanaceous plants in the south of Brazil, p. 339-363. In: P. H. A. Jolivet, \& M. L. Cox (eds.). Chrysomelidae Biology, vol. 2: Ecological studies. SPB Academic Publishing, Amsterdam, vi+465 p.

Medeiros, L.; D. S. Boligon \& G. R. P. Moreira. 2004. Morphological and behavioral adaptations to movement on different leaf surfaces: studies with cassidine larvae, p. 291-303. In: P. H. Jolivet, J. A.Santiago-Blay, and M. Schmidt (eds.). New Contributions to the Biology of Chrysomelidae. SPB Academic Publishers, $\mathrm{xvi}+804 \mathrm{p}$.

Mentz, L. A.; P. L. Oliveira \& M. V. Silva. 2000. Tipologia dos tricomas das espécies do gênero Solanum (Solanaceae) na Região Sul do Brasil. Iheringia, Série Botânica 54: 75-106.

Moran, N. A. 1986. Morphological adaptation to host plants in Uroleucon (Homoptera; Aphididae). Evolution 40: 1044-1050.

Neal, J. J.; J. C. Stephens \& W. M. Tingey. 1989. Glandular trichomes of Solanum berthautii and resistance to the Colorado potato beetle. Entomologia Experimentalis et Applicata 51: 133-140.

Nogueira de Sá, F.; L. Medeiros \& M. V. Macêdo. 2004. Phenology of Cassidinae populations in Brazil, p. 647-658. In: P. H. Jolivet; J. A. Santiago-Blay \& M. Schmidt. (eds.). New Developments on the Biology of Chrysomelidae. SPB Academic Publishers, $\mathrm{xvi}+804 \mathrm{p}$.

Obrycki, J. J. \& M. J. Tauber. 1984. Natural enemy activity on glandular pubescent potato plants in the greenhouse: an unreliable predictor of effects in the field. Environmental Entomology 13: 679683.

Olckers, T.; J. C. Medal \& D. E. Gandolfo. 2002. Insect herbivores associated with species of Solanum (Solanaceae) in northeastern Argentina and southeastern Paraguay, with reference to biological control of weeds in South Africa and the United States of America. Florida Entomologist 85: 254-260.

Pillemer, E. A. \& W. M. Tingey. 1976. Hooked trichomes: a physical plant barrier to a major agricultural pest. Science 193: 482-484.

Ramalho, F. S.; W. R. Parrot; J. N. Jenkins \& J. C. McCarty, Jr. 1984. Effects of cotton leaf trichomes on the mobility of newly hatched tobacco budworms (Lepidoptera: Noctuidae). Journal of Economic Entomology 77: 619-621. 
Rathcke, B. J.; R. W. \& Poole. 1974. Coevolutionary races continues: larval adaptation to plant trichomes. Science 187: 175-176.

Schillinger Jr., J. A. \& R. L. Gallun. 1968. Leaf pubescence of wheat as a deterrent to the cereal leaf beetle, Oulema melanopus. Annals of the Entomological Society of America 61: 900-903.

Shade, R. E.; M. J. Doskocil \& N. P. Maxon. 1979. Potato leafhopper resistance in glandular-haired alfafa species. Crop Science 19: 287-289.

Shah, M. A. 1982. The influence of plant surfaces on the searching behaviour of coccinelid larvae. Entomologia Experimentalis et Applicata 31: 377-380.

Siebert, M. W. 1975. Candidates for the biological control of Solanum elaegnifolium Cav. (Solanaceae) in South Africa: Laboratory studies on the biology of Gratiana lutescens (Boh.) and Gratiana pallidula (Boh.) (Coleoptera, Cassididae). Journal of the Entomological Society of South Africa 38: 297-304.

Smith, R. L.; R. L. Wilson \& F. D. Wilson. 1975. Resistance of cotton plant hairs to mobility of first-instars of the Pink Bollworm. Journal of Economic Entomology 68: 679-683.

Smith, S. \& G. Grodowitz. 1983. Effects on nonglandular trichomes of Artemisia ludoviciana Nutt. (Asteraceae) on ingestion, assimilation, and growth of the grasshoppers Hypochlora alba (Dodge) and Melanoplus sanguinipes (F.) (Orthoptera: Acrididae). Environmental Entomology 12: 1766-1772.

Southwood, T. R. E. 1986. Plant surfaces and insects - an overview, p. 1-22. In: B. Juniper \& T. R. E. Sowthwood (eds.). Insects and the plant surface. Edward Arnold Publishers, London, viii+360 p.

Thurston, R. 1970. Toxicity of trichome exudates of Nicotiana and Petunia species to tobacco hornworm larvae. Journal of Economic Entomology 63: 272-274.

Tingey, W. M. \& J. E. Laubengayer. 1981. Defense against the green peach aphid and potato leafhopper by glandular trichomes of Solanum berthaultii. Journal of Economic Entomology 74: 721725 .

Tingey, W. M. \& R. W. Gibson. 1978. Feeding and mobility of the potato leafhopper impaired by glandular trichomes of Solanum berthaultii and $S$. polyadenium. Journal of Economic Entomology 71: 856-858.

Valverde, P. L.; J. Fornoni \& J. Núñez-Farfán. 2001. Defensive role of leaf trichomes in resistance to herbivorus insects in Datura stramonium (Solanaceae). Journal of Evolutionary Biology 14: 424-432.

Van Dam, N. M. \& J. D. Hare. 1998. Biological activity of Datura wrigthii (Solanaceae) glandular trichome exudate against Manduca sexta (Lepidoptera: Sphingidae). Journal of Chemical Ecology 24: $1529-1549$

Wagner, G. J.; E. Wang \& R.W. Shepherd. 2004. New approaches for studying an old protuberance, the plant trichomes. Annals of Botany 93: 3-11.

Wellso, S. G. \& R. P. Hoxie. 1988. Biology of Oulema, p. 497-511. In: P. Jolivet; E. Petitpierre \& T. H. Hsiao (eds.). Biology of Chrysomelidae. Kluwer Academic Publishers, Dordrecht, xxiv+615 p.

Yencho, G. C. \& W. M. Tingey. 1994. Glandular trichomes of Solanum berthautii alter host preference of the Colorado potato beetle, Leptinotarsa decemlineata. Entomologia Experimentalis et Applicata 70: 217-225.

Zalucki, M. P. 2001. It's the first bites that count: Survival of firstinstar monarchs on milkweeds. Austral Ecology 26: 1-9.

Zalucki, M. P.; A. R. Clarke \& S. B. Malcon. 2002. Ecology and behavior of first instar larval Lepidoptera. Annual Review of Entomology 47: 361-393.

Received 20/12/2005; accepted 16/05/2007 